\title{
In vitro evaluation of the effects of risedronate associated with cobalamin on osteoblastic cells
}

\author{
Avaliação in vitro dos efeitos do risedronato associado à cobalamina sobre células osteoblásticas
}

Jaqueline Aparecida FIUZA ${ }^{1}$

Elizabeth Ferreira MARTINEZ1

Rui Barbosa de BRITO JÚNIOR'

\section{ABSTRACT}

\section{Objective}

To evaluate the action of risedronate and cobalamin, and effects when associated, when administered osteoblastic cells.

\section{Methods}

The MC3T3 cells were cultivate in the media $\alpha-M E M$ and $\alpha-M E M$ supplemented with mineralizing factors, ascorbic acid and disodium $\alpha$-glyicerophosphate, and treated with risedronate, cobalamin, and risedronate associated with cobalamin in a concentration of $10^{-3} \mathrm{M}$. The cell proliferation and formation of calcium and phosphate nodules were evaluated at 24 hours, 48 hours, 72 hours, 5 days and 7 days via a Neubauer Chamer count, Alizarin and the von Kossa reaction.

\section{Results}

The results showed that the growth curve for cell proliferation and the formation of mineral nodules was similar for both cultures analyzed.

\section{Conclusion}

The conclusion was reached that using risedronate, cobalamin and both drugs in combination on osteoblastic cell cultures does not cause alterations to their growth or in the formation of calcium and phosphate nodules.

Indexing terms: Vitamin B 12. Osteoblasts. Osteoporosis.

\section{RESUMO}

\section{Objetivo}

Avaliar a ação do risedronato e da cobalamina, e seus efeitos quando associados, em células osteoblásticas.

\section{Métodos}

Células MC3T3 foram cultivadas em meio $\alpha$-MEM e $\alpha$-MEM suplementado com fatores mineralizantes, ácido ascórbico e $\alpha$-glicerofosfato dissódico, e tratadas com: risedronato, cobalamina, e risedronato associado à cobalamina na concentração de $10^{-3} \mathrm{M}$. A proliferação celular e formação de nódulos de cálcio e fosfato foram avaliados após 24 horas, 48 horas, 72 horas, 5 dias e 7 dias, através de contagem em Câmara de Neubauer, vermelho de Alizarina e Reação de von Kossa.

\section{Resultados}

Os resultados mostraram que não houve diferenças significativas na curva de crescimento e formação de nódulos minerais entre as culturas analisadas.

\section{Conclusão}

Concluiu-se que a utilização do risedronato, da cobalamina e associação de ambas em cultura de células osteoblásticas, não provocaram alterações no crescimento e formação de nódulos de cálcio e fosfato.

Termos de indexação: Vitamina B12. Osteoblastos. Osteoporose.

\footnotetext{
${ }^{1}$ Faculdade São Leopoldo Mandic, Curso de Odontologia, Programa de Pós-Graduação em Implantodontia. Rua José Rocha Junqueira, 13, Swift, 13045-755, Campinas, SP, Brasil. Correspondência para / Correspondence to: JA FIUZA. Email: < jqfiuza@ig.com.br>.
} 


\section{INTRODUCTION}

The homeostasis of bone tissue is influenced by systemic factors of nutritional, pharmacological, endocrine and pathological origin. Accordingly, a diet rich in vitamins and mineral salts insures that it functions well, from its initial formation in the uterus to its decline in the adult phase. It may be attacked by a variety of pathologies that affect its metabolism, such as osteoporosis, one of the more common, with its slow, asymptomatic progression, first described by Albright et al. ${ }^{1}$ in 1941, related to postmenopausal estrogen deficiency and to endocrine, gastrointestinal and rheumatological pathogens, causing a reduction in bone mass and alterations to its microarchitecture.

The increase in the elderly population across the globe and consequently the higher rates of osteoporosis, has meant that a large number of people are being subjected to treatment with bisphosphonates, particularly alendronate and risedronate.

The action mechanism of bisphosphonates like risedronate, consists of it binding to the minerals of the bone matrix and, as the latter is reabsorbed, the drug is slowly released causing an increased concentration in the middle of the osteoclasts where their main job is to render them inactive ${ }^{2}$. This drug can preserve and increase bone mass, reducing the risk of bone fracture, with low rates of adverse reaction upon administration ${ }^{3-4}$.

Gangoiti et al. ${ }^{5}$ demonstrated, in a study carried out using osteoblastic cells, that bisphosphonates do not cause cytotoxic action when administered to the cell culture in the period between 24 and 72 hours, and are capable of reversing the harmful effects of glycation in osteoblasts in patients with osteoporosis and diabetes mellitus. Its effectiveness in reducing bone resorption has been proven in comparative clinical studies after a period of 24 months administering the drug ${ }^{6-7}$.

Bone biopsies conducted on patients who, over a long period, have been given bisphosphonates for treatment of osteoporosis and who had suffered fractures, detected the presence of giant osteoclasts suggesting that prolonged use could cause osteoclastic mutations and bone fractures ${ }^{8}$.

The prevalence of osteoporosis and bone fractures may be connected with other factors such as cobalamin deficiency and increased levels of homocysteine caused by the low concentration of cobalamin ${ }^{9}$.

Studies suggest that the low concentration of vitamin $B$ in blood plasma is associated with a reduction in bone mineral density, an increase in bone loss and the risk of osteoporotic fracture through the promotion of osteoclast activity, while high concentrations stimulate bone formation and osteoblast activity ${ }^{10-11}$.

Cobalamin deficiency raises the secretion of homocysteine and methylmalonic acid which induce osteoclastogenesis in a dose-dependent manner and alter the reticulation of the collagen, so cobalamin deficiency may lead to the reduction in bone mass due to the increased formation of osteoclastic cells and, consequently, increased risk of fracture ${ }^{12-13}$.

The aim of the study was to evaluate the action of risedronate and cobalamin, as well as their effects when combined, acting on osteoblastic cells.

\section{METHODS}

This study was carried out in accordance with the guidelines on osteoblastic cells for the protection of the human research subject, established by the Ministry of Health's National Health Council, per the Animal Experimentation Ethics Committee at the São Leopoldo Mandic School of Dentistry and Dental Research Center, under record no. 2009/0181.

\section{Cell lines}

Cell lines of mouse calvarial osteoblasts (MC3T3) (figure 5) were obtained from the ATCC (American Type Culture Collection).

\section{Cell culture}

The osteoblastic cells were cultivated in an alphamodified Minimal Essential Medium ( $\alpha$-MEM) (Nutricellò, Campinas, Brazil) supplemented with $10 \%$ bovine fetal serum (Cultilab, Campinas, SP, Brazil) and 1\% antibiotic/ antimycotic solution (Sigma, St. Louis, Missouri, USA) ${ }^{14}$. In order to compare the effects of the risedronate and the cobalamin on cell proliferation and viability, as well as the formation of mineralized nodules, the same MEM- $\alpha$ medium was used and a combination of MEM- $\alpha$ medium supplemented with mineralization factors, $10 \mathrm{mM}$ of $\beta$-glycerophosphate (Sigma ${ }^{\circledR}$ ) and $50 \mu \mathrm{g} / \mathrm{ml}$ of ascorbic acid $\left(\text { Invitrogen }{ }^{\circledR}\right)^{15-16}$.

The MC3T3 cells were laid out on 15 plates in 24 wells, at a density of 55 cells per $\mathrm{mm}^{2}$, in each well.

All the procedures were carried out in a laminar flow hood in order to keep sterile the materials and substances used for the cell culture. 
The cells were kept in an oven at $37^{\circ} \mathrm{C}$ in a damp atmosphere containing 95\% air and 5\% carbon dioxide. The culture medium was changed every other day and the progress of the culture was evaluated under a light microscope.

The cells were used in the following experiments for the study of cell proliferation as well as the identification of the presence of calcium and phosphate in nodular areas of mineralized matrix, evidenced by the colors red and black, respectively, using the Alizarin-red and von Kossa histochemical methods ${ }^{17}$.

\section{Drug supplementation}

Twenty-four hours after the cell plating, the cells were treated with risedronate (Risedross ${ }^{\circledR} 35 \mathrm{mg}$ ) in a concentration of $10^{-3} \mathrm{M}$, and cobalamin or vitamin B12 (Rubranova ${ }^{\circledR} 5000$ ) in a concentration of $10^{-3} \mathrm{M}$, for time periods of 24 hours, 48 hours, 72 hours, 5 days and 7 days. The cells were incubated under standard cell cultivation conditions $\left(37^{\circ} \mathrm{C}, 95 \%\right.$ humidity and $\left.5 \% \mathrm{CO}_{2}\right)$ and the culture medium was changed every other day.

\section{Cell proliferation}

In order to evaluate cell proliferation, the exclusion method was employed using the vital stain Trypan blue.

The plates containing the cells were individually separated via trypsinization. The cells in suspension were centrifuged for five minutes at a speed of $200 \mathrm{rpm}$. The precipitate was resuspended in $1 \mathrm{ml}$ of $\alpha$-MEM medium and to $0.1 \mathrm{ml}$ of this cell suspension was added $0.8 \mathrm{ml}$ of PBS and $0.1 \mathrm{ml}$ of Trypan blue stain $0.4 \%$.

The cell suspension was arranged in a hemocytometer (Neubauer Chamber), and counted under a light microscope. The number of live or viable cells and the number of dead or non-viable cells were recorded.

The total number of cells present on the plate was obtained by multiplying the total number of cells counted through the dilution by $10^{4}$, divided by the number of quadrants used for the count.

The exclusion of the dead cells, only stained by Trypan blue, served as the basis for determining cell viability. Thus, the total number of viable cells, unstained and thus vital, was obtained by excluding the dead cells from the equation performed to obtain the total number of cells present on the plate.

The percentage viability of the cell population was obtained by dividing the total number of viable cells by the total number of cells, and multiplying by one hundred ${ }^{18}$.

\section{Histochemical methods}

\section{Alizarin Red}

Once the experiment times had elapsed, $0.5 \mathrm{ml}$ of medium were removed from the culture wells. They were rinsed twice in Hanks' solution (Sigma ${ }^{\circledR}$, reference H6136), comprising $90 \%$ water and $0.35 \mathrm{~g}$ bicarbonate of soda. They were then fixed in 70\% ethyl alcohol for 1 hour at $4^{\circ} \mathrm{C}$. They were then washed in a phosphate buffer (PBS) to remove the residue, then in distilled water for incubation in Alizarin (solution composed of $1 \mathrm{~g}$ of alizarin powder and $50 \mathrm{ml}$ of distilled water, heated to $45^{\circ} \mathrm{C}$, and after cooling left in a pH of 4.3 and kept at room temperature for fifteen minutes). At the end of this period, they were copiously washed in distilled water and then in PBS for fifteen minutes. At the end of this time, the wells were washed again in distilled water, the glass slides were removed from inside the wells and placed on filter paper, thereby commencing the process of drying at room temperature.

The use of this histochemical staining method permitted an evaluation of the formation of mineralized calcium nodules.

\section{von Kossa}

After the appropriate period of time, $0.5 \mathrm{ml}$ of each culture was removed, and incubated in a solution of $2 \mathrm{ml}$ of silver nitrate $(0.25 \mathrm{~g}$ of silver nitrate in $50 \mathrm{ml}$ of distilled water) for 20 minutes. They were then washed, twice, in distilled water and immersed in a solution of $2 \mathrm{ml}$ hydroquinone $(0.25 \mathrm{~g}$ hydroquinone in $50 \mathrm{ml}$ of distilled water) for 2 minutes. At the end of this period of time, the material was removed without being washed and placed in a solution of $2 \mathrm{ml}$ thiosulfate $(2.5 \mathrm{~g}$ thiosulfate in 50 $\mathrm{ml}$ of distilled water) for 2 minutes. After resting in this solution, the material was washed twice in distilled water and immediately dried.

By way of this histochemical method, the staining of the mineralized phosphate nodules was obtained.

\section{Evaluation of histochemical methods}

After the procedure of staining the calcium and phosphate nodules, these were qualitatively evaluated under a light microscope via the scanning of the observed field.

\section{Statistics}

For the data obtained in relation to viable and non-viable cells, a statistical analysis was performed to find 
the mean, standard error and median values. The standard error is a precision measurement of the calculated sample mean. Due to the fact that the experiment has three identical repetitions, standard deviation was not used ${ }^{19}$.

The factor ANOVA test was used to find out if there is a significant difference between the means and if the factors exert an influence on any dependent variable ${ }^{20}$.

At the end of the factor ANOVA test, if there is significance between the treatments, a mean comparison test should be used to complement the variance analysis and, in this case, the Tukey test was employed ${ }^{21}$.
Fisher's exact test was also used as it directly supplies the p-value without using intermediary statistics to compare qualitative data in the experiment ${ }^{22}$.

\section{RESULTS}

The data compared for viable and non-viable cells in the $\alpha$-MEM medium and the $\alpha$-MEM medium supplemented with ascorbic acid and disodium $\beta$-glycerophosphate, considering the timing as the analytical factor, are explained in Figure 1.

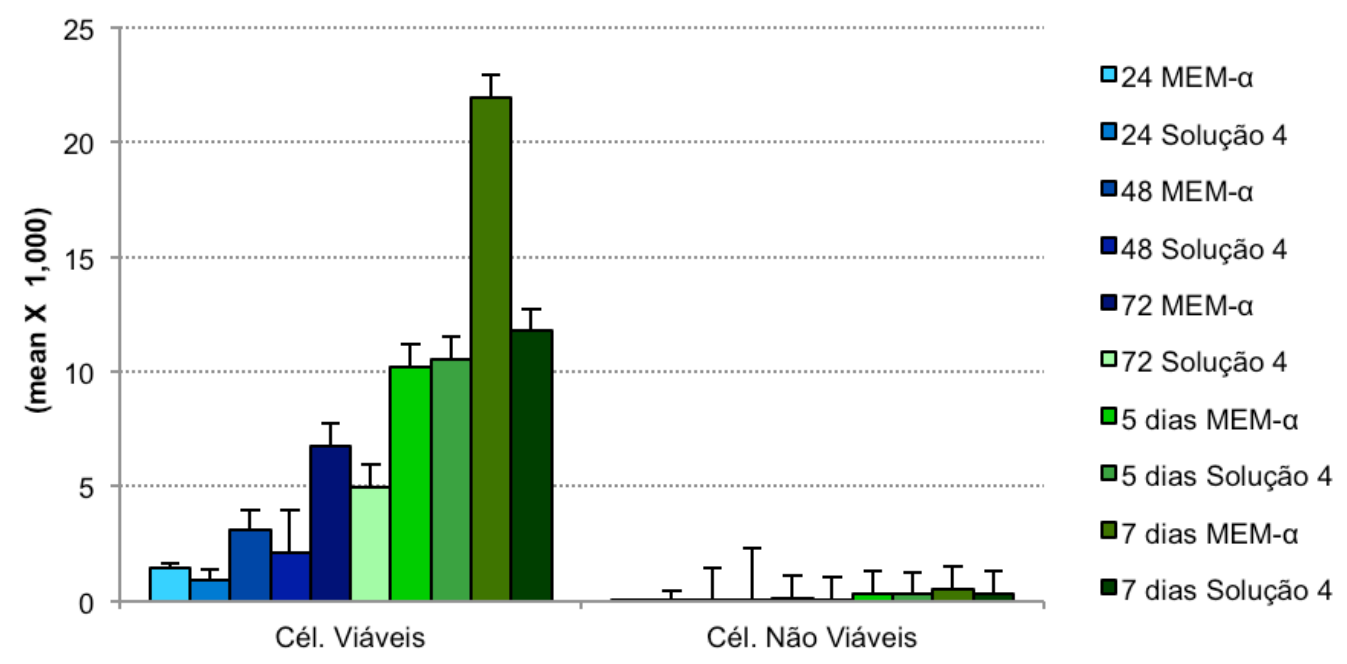

Figure 1. Comparison between the data obtained for viable and non-viable cells at points in time between 24 hours and 7 days, in $\alpha$-MEM and supplemented $\alpha$-MEM.

The data obtained from the samples at 24 hours, 48 hours, 72 hours, 5 days and 7 days, for viable and non-viable cells, were compared between the culture media analyzed in the experiment, namely $\alpha$-MEM and supplemented $\alpha$-MEM.

The statistical values obtained for viable cells demonstrated that the $p$-values remained flat in the samples at 24 hours, 48 hours, 72 hours and 5 days, due to the small numerical variance observed between the two media ( $p>$ 0.05). There was significance between the samples at 7 days, a larger number of viable cells being observed in the $\alpha$-MEM culture medium when compared to the supplemented $\alpha$-MEM medium in the same period $(p<0.05)$.

The data relating to non-viable cells at the evaluated points in time in the experiment were statistically analyzed to observe if there was a difference between the samples at the same times with different culture media.
There was significance in the sample at 48 hours when the $\alpha$-MEM and supplemented $\alpha$-MEM culture media were compared at this point in time $(p<0.05)$. The other times analyzed for the two media did not show any significance between each other $(p>0.05)$.

The data obtained in the experiment for viable and non-viable cells were compared as to a possible difference between the analyzed culture media. It was observed that there was statistical significance when comparing cells in terms of the culture medium used, $\alpha$-MEM medium and the supplemented $\alpha$-MEM medium, giving $p$-values $<0.05$ $(p<0.05)$, for both viable and non-viable cells.

It was found that there was a significant difference in relation to the effect of treatment time on the cell culture, as well as between the culture media used in the experiment $(p<0.05)$. According to the test, the other evaluated factors did not present statistical significance $(p>0.05)$. 
For the experimental samples where the Alizarin red tests were carried out with the aim of observing calcium nodule formations, a qualitative statistical test was applied, based on an analysis of the cultures under the microscope. The qualitative analysis evaluated the formation of calcium nodules in treatments with risedronate, cobalamin, risedronate and cobalamin combined and in the control, compared to one another, in relation to the medium used, the time of the experiment and the interaction between time and culture medium for the different treatments. This analysis proved negative as no calcium nodule formation took place.

At 7 days, the von Kossa reaction revealed the formation of phosphate nodules in $\alpha$-MEM and supplemented $\alpha$-MEM for all the treatments used. Fisher's exact test was used to analyze these data $(p=1)$.

The analysis of the von Kossa reaction was performed under a microscope at a magnification of 200x; the figures below show the image of the nodules found at the end of the experiment.

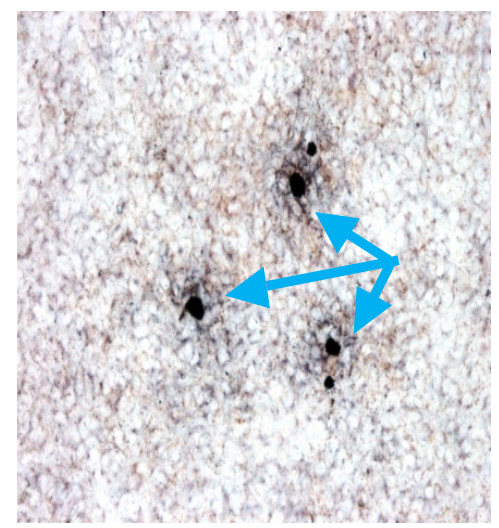

Figure 2. Micrograph of osteoblastic cells treated with risedronate and cobalamin in supplemented $\alpha$-MEM at 7 days. Von Kossa Stain Reaction. 200x magnification. The arrows are pointing towards the phosphate nodules.

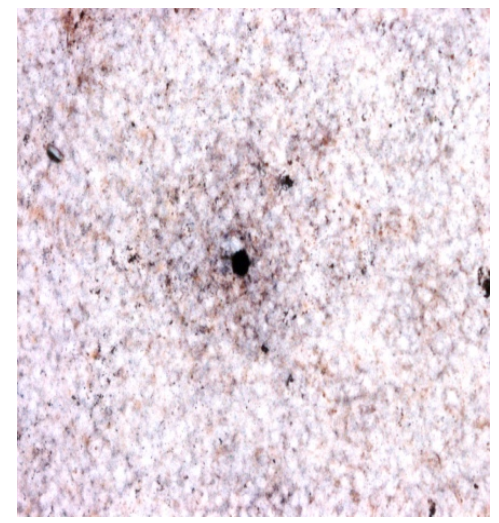

Figure 3. Micrograph of untreated osteoblastic cells (control) in supplemented $\alpha$-MEM at 7 days. Von Kossa Stain Reaction. 200x magnification. The arrows are pointing towards the phosphate nodule.

\section{DISCUSSION}

The growth of osteoblastic cells cultivated in the $\alpha$-MEM medium and $\alpha$-MEM medium supplemented with ascorbic acid and disodium $\beta$-glycerophosphate, remained unaltered upon administration of risedronate to the culture medium, comparing all the times evaluated with the control group. This demonstrates that this drug apparently does not possess cytotoxic action nor does it interfere with cell proliferation. Gangoiti et al. ${ }^{5}$ obtained similar results to this study using the same type of MC3T3 cells and bisphosphonates.

The low cytotoxicity with the use of risedronate was also observed in the studies of Graham et al. ${ }^{2}$, Dane et al. ${ }^{3}$ and Ferrari et al. ${ }^{7}$, Syversen and Halse ${ }^{23}$.

After analysis under a light microscope, it was found that the media in which cobalamin was administered had a larger number of live cells, forming a cell pool at 48 hours, 72 hours, 5 days and 7 days, in the three experimental repetitions. A visible increase in cell growth, in the culture medium treated with cobalamin, was also reported by Kim et al. ${ }^{10}$, correlating hypovitaminosis B with the incidence of osteoporosis. This piece of data suggests that cobalamin could have a positive influence on osteoblast activity, as also observed by Stone et al. ${ }^{11}$, McLean et al. ${ }^{23}$ and Yazdanpanah et al. ${ }^{25}$. With the isolated administration of cobalamin to the MC3T3 osteoblastic cells, in both culture media, it was noted that cell development and growth continued to be similar to the other samples analyzed when the cells were counted in the Neubauer chamber.

The combination of the drugs risedronate and cobalamin kept the cultivated cells viable, promoting growth without cytotoxic alterations, which has never been reported in the literature.

According to the statistical data for viable cells, the $\alpha$-MEM culture medium obtained the highest cell growth curve out of all the treatments applied in the study at 7 days, including in the control group, when compared to the supplemented $\alpha$-MEM. It is believed that this outcome is due to the inducing properties of mineral deposition and cell mineralization present in the $\alpha$-MEM culture medium supplemented with ascorbic acid and disodium $\beta$-glycerophosphate, which could lead to a reduction in the process of bone cell proliferation ${ }^{15}$.

As for the results relating to non-viable cells, there was significance at 48 hours between the culture media used, the highest number of non-viable cells being found in the $\alpha$-MEM medium. For the other times evaluated, 
the difference between one another and between culture media was small. Thus the statistical significance which was only found at 48 hours represents an isolated piece of information and does not modify the results observed in the study.

Stability with the formation of calcium nodules was nondescript for the administration of the drug, in agreement with the reports by Gangoiti et al. ${ }^{5}$, Graham et al. ${ }^{2}$, Dane et al. ${ }^{3}$, Qiu et al. ${ }^{6}$ and Ferrari et al. ${ }^{7}$.

Via the von Kossa reaction applied in this study, the formation of phosphate nodules at 7 days could be observed, in all samples, the outcome being invariable between one another, irrespective of the drug used.

In contrast to the results found in this study with the action of risedronate, Jain \& Weinstein ${ }^{8}$, after bone biopsies on patients who had suffered recent vertebral fractures, and making use of bisphosphonates for a long period of time for the treatment of osteoporosis, observed giant osteoclasts with over 40 nuclei in each cell and demonstrated that the prolonged use of oral bisphosphonates could cause mutations in osteoclastic cells and, consequently, bone fractures.

Ruggiero et al. ${ }^{26}$, Greenberge ${ }^{27}$, Ficarra et al. $^{28}$ and Melo and Obeid ${ }^{29}$ reported osteonecrosis in patients who constantly used bisphosphonates and who underwent dental interventions involving alveolar bone tissue. Apoptosis in osteoblastic cells was also reported by Wang et al. ${ }^{30}$ after variations in the applied doses of risedronate.

Due to the degree of complexity of the bone system, additional refining, clinical studies are required to obtain effective proof of the use of these drugs, chiefly cobalamin, in maintaining and repairing bone tissue.

This was a preliminary study which, in view of the results obtained, it is suggested should be continued, altering the timing and/or concentration of the drugs, and the use of guinea pigs to observe possible improvements in bone health and the overall health in humans with the use of these drugs.

\section{CONCLUSION}

It is concluded that the use of risedronate, cobalamin and a combination of the two, in osteoblastic cell cultures, does not alter cell proliferation or interfere with the formation of mineral nodules, in the in vitro conditions evaluated.

\section{Collaborators}

JA FIUZA, EF MARTINEZ and RB BRITO JÚNIOR took part in all the stages of preparation of this article.

\section{REFERENCES}

1. Albright $F$, Smith $\mathrm{PH}$, Richardson AM. Postmenopausal osteoporosis. JAMA. 1941;116:2465-74.

2. Graham R, Russel G, Dunford JE, Oppermann U, Kwaasi A, Hulley PA, et al. Bisphosphonates: an update on mechanisms of action and how these relate to clinical efficacy. Ann N Y Acad Sci. 2007;1117:209-57. doi: 10.1196/annals.1402.089

3. Dane C, Dane B, Cetin A, Erginbas M. Effect of risedronate on biochemical marker of bone resorption in postmenopausal women with osteoporosis or osteopenia. Gynecol Endrocrinol. 2008;24(4);207-13. doi: 10.1080/09513590801895617

4. Rizzoli R. Bisphosphonates for post-menopausal osteoporosis: are they all the same? QJM. 2011;104(4):281-300. doi: 10.1093/ qjmed/hcq259

5. Gangoiti MV, Cortizo AM, Arnol V, Felice Jl, McCarthy AD Opposing effects of bisphosphonates and advanced glycation end-products on osteoblastic cells. Europ J Pharmacol. 2008;600:140-7. doi: 10.1016/j.ejphar.2008.10.031

6. Qiu S, Phipps RJ, Ebetino FH, Palnitkar S, Sudhaker Rao D. Effect of Risedronate on Osteocyte Viability and Bone Turnover in Paired Iliac Bone Biopsies from Early Postmenopausal Women. Calcif Tissue Int. 2010;87(5):392-7. doi: 10.1007/ s00223-010-9411-y

7. Ferrari S, Nakamura T, Hagino H, Fujiwara S, Lange JL, Watts NB. Longitudinal change in hip fracture incidence after starting risedronate or raloxifene: an observational study. J Bone Miner Metab. 2011;29(5):561-70. doi: 10.1007/s00774-010-0249-1.

8. Jain N, Weinstein R. Giant osteoclasts after long-term bisphosphonates therapy: diagnostic challenges. Nature Rev Rheumatol. 2009;5(6):341-6. doi: 10.1038/nrrheum.2009.87 
9. Carmel R, Lau KH, Baylink DJ, Saxena S, Singer FR. Cobalamin and osteoblast-specific proteins. N Engl J Med. 1988;319(2):705. doi: 10.1056/NEJM198807143190202

10. Kim GS, Kim CH, Park JY, Lee KU, Park CS. Effects of vitamin B-12 on cell proliferation and cellular alkaline phosphatase activity in human bone marrow stromal osteoprogenitor cells and UMR106 osteoblastic cells. Metabolism. 1996;45(12):1443-6.

11. Stone $K L$, Bauer DC, Sellmeyer D, Cummings SR. Low serum vitamin B-12 levels are associated with increased hip bone loss in older women: a prospective study. J Clin Endocrinol Metab. 2004;89(3):1217-21. doi: http://dx.doi.org/10.1210/jc.2003030074

12. Herrman M, Schmidt J, Umanskaya N, Colaianni G, Al Marrawi F, Widmann T. Stimulation of osteoclast activity by low B-vitamin concentrations. Bone. 2007;41(4):584-91. doi:10.1016/j. bone.2007.06.005

13. Herrmann W, Hermann M. Is hyperhomocysteinemia a risk factor for osteoporosis? Exp Rev Endocrinol Metabol. 2008;3(3):30913. doi:10.1586/17446651.3.3.309

14. Coelho MJ, Trigo Cabral A, Fernandes MH. Human bone cell cultures in biocompatibility testing. Part I: osteoblastic differentiation of serially passaged human bone marrow cells cultured in $\alpha$-MEM and in DMEM. Biomaterials 2000;21(11):1087-94. doi:10.1016/S0142-9612(99)00284-7

15. Coelho MJ, Fernandes MH. Human bone cell cultures in biocompatibility testing. Part II: effect of ascorbic acid, $\beta$-glycerophosphate and dexamethasone on osteoblastic differentiation. Biomaterials. 2000;2(11):1095-102. doi:10.1016/S0142-9612(99)00192-1

16. Oliveira PT, Zalzal SF, Irie K, Nanci A. Early expression of bone matrix proteins in osteogenic cell cultures. J Histochem Cytochem. 2003;51(5):633-41. doi: 10.1177/002215540305100509

17. Bonewald LF, Harris SE, Rosser J, Dallas MR, Dallas SL, Camacho $N P$, et al. von Kossa staining alone is not sufficient to confirm that mineralization in vitro represents bone formation. Calcif Tissue Int. 2003;72(5):537-47.

18. Freshney, RY. Culture of animal cells: a manual of basic technique. $5^{\text {th }}$ ed. New Jersey: John Wiley \& Sons; 2005.

19. Paes AT. Por dentro da Estatística. Einstein Educ Contin Saú. 2008;6(3):107-8.

20. Martins GA. Estatística geral e aplicada. $3^{a}$ ed. São Paulo: Atlas; 2005.
21. Duarte M. Teste de comparação de média e Teste de Tukey. [text on internet. 2010 [cited 2010 Nov 26]. Available at: http://www. infoescola.com/estatistica/teste-de-comparacao-de-mediasteste-de-tukey/.

22. Martins GA. Estatística geral e aplicada. $4^{a}$ ed. São Paulo: Atlas; 2011.

23. Syversen U, Halse J. Bisphosphonate treatment of osteoporosis and other skeletal diseases. Tidsskr Nor Laegeforen. 2011;131(3):244-7. doi: 10.4045/tidsskr.09.0470

24. McLean RR, McLean MPH, Jacques PF, Selhub J, Tucker KL, Samelson EJ. Homocysteine as a predictive factor for hip fracture in older persons. N Engl J Med. 2004;350(20):2042-9. doi: 10.1056/NEJMoa032739

25. Yazdanpanah N, Zillikens MC, Rivadeneira F, Jong R, Lindemans J, Uitterlinden AG. Effect of dietary B vitamins on BMD and risk of fracture in elderly men and women: The Rotterdam Study. Bone. 2007;41(6):987-94. doi:10.1016/j.bone.2007.08.021

26. Ruggiero SL, Mehrotra B, Rosenberg TJ, Engroff SL. Osteonecrosis of the jaws associated with the use of bisphosphonates: a review of 63 cases. J Oral Maxillofac Surg. 2004;62(5):527-34. doi:10.1016/j.joms.2004.02.004

27. Greenberg MS. Intravenous bisphosphonates and osteonecrosis. Oral Surg Oral Med Oral Pathol Oral Radiol Endod. 2004;98(3):259-60.

28. Ficarra G, Beninati F, Rubino I, Vannucchi A, Longo G, Tonelli $\mathrm{P}$, et al. Osteonecrosis of the jaws in periodontal patients with a history of bisphosphonates treatment. J Clin Periodontol. 2005;32(11):1123-8. doi: 10.1111/j.1600-051X.2005.00842.x

29. Melo MD, Obeid G. Osteonecrosis of the maxilla in a patient with a history of bisphosphonates therapy. J Canad Assoc. 2005;71(2):111-13.

30. Wang J, Stern PH. Dose-dependent differential effects of risedronate on gene expression in osteoblasts. Biochem Pharmacol. 2011;81(8):1036-42. doi: 10.1016/j. bcp.2011.01.025
Received on: 25/8/2014

Final version resubmitted on: 17/12/2014 Approved on: 12/3/2015 
